\title{
MEKANISME PENERBITAN PERPPU NOMOR 1 TAHUN 2013 TENTANG PERUBAHAN KEDUA ATAS UU NOMOR 24 TAHUN 2003 TENTANG MAHKAMAH KONSTITUSI DALAM KAIDAH KEGETINGAN YANG MEMAKSA
}

\author{
Fernando Silalahi \\ Rupertus Arvinci Ngabut \\ fernando.irsh@yahoo.com \\ Universitas Kristen Indonesia, Jakarta, Indonesia
}

\begin{abstract}
Indonesian President Susilo Bambang Yudhoyono signed Government Regulation in Lieu of Law No. 1 of 2013 concerning the Second Amendment to Law No.24 of 2003 concerning the Constitutional Court, which was an-nounced by Coordinating Minister for Political, Legal and Security Affairs (Menkopolhukam) Djoko Suyanto, in Gedung Agung Yogyakarta on October 17, 2013 Special Region of Yogyakarta (DIY). After the previous Saturday, October 5, 2013, the President met with leaders of state institutions at the State Palace. The meeting recommended ve agendas and steps to save the Constitutional Court (MK), and was announced directly by the President
\end{abstract}

Keyword: government regulation; second amendment; constitutional court

\section{PENDAHULUAN}

Presiden R.I Susilo Bambang Yudhoyono menandatangani Peraturan Pemerintah Pengganti Undang-Undang (PERPPU) No.1 Tahun 2013 ten-tang Perubahan Kedua atas UU No.24 Tahun 2003 tentang Mahkamah Konstitusi, yang diumumkan oleh Menteri Koordinator Politik Hukum dan Keamanan (Menkopolhukam) Djoko Suyanto, di Gedung Agung Yogyakarta pada tanggal 17 Oktober 2013 Daerah Istimewa Yogyakarta (DIY). Setelah sebelumnya Sabtu, 5 Oktober 2013, Presiden bertemu dengan pimpinan lembaga negara ${ }^{1}$ di Istana Negara. Pertemuan tersebut merekomendasikan lima agenda dan langkah penyelamatan Mahkamah Konstitusi (MK), dan diumumkan langsung oleh Presiden. Lima agenda dan langkah penyelamatan MK tersebut sebagai berikut:

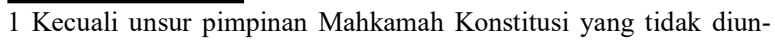
dang.
- Pertama: Persidangan MK diharapkan dengan hati-hati jangan sampai ada penyimpangan baru.

- Kedua: Penegakan hukum yang dilaksanakan KPK dapat dilaksanakan dengan cepat dan konk-lusif, agar kepercayaan rakyat kepada MK pulih kembali.

- Ketiga: Presiden berencana mengeluarkan PERPPU yang akan diajukan kepada DPR untuk mengatur persyaratan, aturan dan mekanisme seleksi hakim MK. Pengaturan tentang itu akan mendengarkan juga masukan dari DPR dan MA.

- Keempat: Dalam PERPPU akan diatur pengawasan terhadap proses peradilan di MK. Komisi Yudisial dapat mengawasi hakim MK, sebagaima-na pengawasan terhadap hakim lain.

- Kelima: Dalam fase konsolidasi yang dilakukan MK, diharapkan MK juga melakukan audit inter- 
nal dan audit external oleh lembaga negara yang memiliki kewenangan untuk itu. ${ }^{2}$

Tujuan diterbitkannya PERPPU MK layak untuk diapresiasi, karena PERPPU MK dikeluarkan oleh Pemerintah dimaksudkan untuk mengembalikan kepercayaan publik terhadap Mahkamah Konstitusi akibat adanya kemerosotan integritas dan kepribadian salah satu hakim konstitusi yang kebetulan menjabat sebagai Ketua MK (nonaktif) Akil Mochtar, yang terjaring 'operasi tangkap tangan'3 oleh KPK menerima suap di rumah dinas Ketua MK dari pihak yang sedang berperkara di MK pada rabu malam, 2 Oktober 2013.

Akibat tertangkapnya Akil Mochtar menimbulkan 'kegaduhan politik' dikalangan masyarakat yang selama ini menumpukan harapan besar kepada MK untuk mengawal agenda reformasi terutama agenda demokrasi Masyarakat hampir tidak percaya adanya peristiwa tertangkapnya jakim MK.

Namun apa boleh dikata, skandal suap yang melibatkan Ketua MK ( nonaktif) ini langsung menghancurkan kredibilitas dan legitimasi putusan-putusan yang telah dikeluarkan bahwa MK merupakan salah satu lembaga negara -selain KPK yang dianggap steril dari praktik korupsi pun memudar.

Poin-poin penting PERPPU MK No.1 Tahun 2013 antara lain, Pemerintah ingin merevisi dan menambah persyaratan untuk menjadi hakim konstitusi, memperjelas mekanisme seleksi dan pengajuan hakim konstitusi, serta perbaikan sistem pengawasan hakim konstistusi.

Pertama, untuk mendapatkan hakim konstitusi yang makin baik, syarat hakim konstitusi, sesuai Pasal 15 ayat (2) huruf i, ditambah "tidak menjadi anggota partai politik dalam jangka waktu paling singkat 7 (tujuh) tahun sebelum diajukan sebagai calon hakim konstitusi”.

Kedua, mekanisme proses seleksi dan pengajuan hakim konstistusi disempurnakan sehingga mem-

2 "Presiden: Ketua MK Berhenti Sementara", Kompas, Minggu, 6 Oktober 2013, Hlm.1.

3 Edy OS Hiariej,”Operasi Tangkap Tangan”,Kompas,Senin,7 Oktober 2013,Hlm.7. perkuat prinsip transparansi, partisipasi, dan akuntabilitas sesuai dengan harapan dan opini publik, yang tercantum pula dalam Pasal 18A UU MK. Untuk itu, sebelum ditetapkan oleh Presiden, pengajuan calon hakim konstitusi oleh MA, DPR dan /atau Presiden, terlebih dahulu dilakukan proses uji kelayakan dan kepatutan yang dilaksanakan oleh Panel Ahli yang dibentuk oleh Komisi Yudisial (KY). Panel ahli beranggotakan tujuh orang yang terdiri dari:

a. Satu orang diusulkan oleh MA;

b. Satu orang diusulkan oleh DPR;

c. Satu orang diusulkan oleh Presiden; dan,

d. Empat orang dipilih oleh KY berdasarkan usulan masyarakat yang terdiri atas mantan hakim konsti-tusi, tokoh mayarakat, akademisi di bidang hukum, dan praktisi hukum.

Ketiga, perbaikan sistem pengawasan hakim kon-stitusi yang lebih efektif dilakukan dengan membentuk Majelis Kehormatan Hakim Konstitusi (MKHK) yang sifatnya permanen, dengan tetap menghormati inde-pendensi hakim konstitusi. Oleh karena itu, MKHK dibentuk bersama oleh Komisi Yudisial (KY) dan MK dengan susunan keanggotaan lima orang, terdiri dari:

a. Satu orang mantan hakim konstitusi;

b. Satu orang praktisi hukum;

c. Dua orang akademisi yang salah satu atau keduanya berlatar belakang di bidang hukum; dan

d. Satu orang tokoh masyarakat.

Dari poin-poin penting dalam PERPPU No.1 Tahun 2013 nampak bahwa sesungguhnya PERPPU tersebut bukan untuk menyelesaikan persoalan jangka pendek, dalam hal ini kredibilitas MK yang jatuh di mata publik karena kasus suap Akil Mochtar, tetapi isinya justru pengaturan untuk jangka panjang. Dalam arti, harus disiapkan sejumlah aktifitas kelembagaan yang membutuhkan waktu lama serta perlu komunikasi kelembagaan negara antara pihak-pihak yang diberi amanah oleh PERPPU tersebut, misalnya MK, KY, DPR, Presiden, dan MA 


\section{PEMBAHASAN}

\section{Sejarah PERPPU}

Sejarah Perundang-undangan di Indonesia dapat dikelompokkan menjadi beberapa bagian, yaitu:

i. Di bawah UUD 1945 (18 Agustus 1945) sampai dengan terbentuknya Negara Republik Indonesia Serikat (27 Desember 1949): jangka waktu 5 (lima) tahun;

ii. Di bawah Konstitusi RIS (27 Desember 1949) sampai dengan ditetapkannya UUD Sementara RI (15 Agustus 1950): jangka waktu 8 (delapan) bulan;

iii. Di bawah UUD Sementara RI (15 Agustus 1950) sampai dengan Dekrit Presiden 5 Juli 19599 tahun s/d 5 Juli 1959;

iv. Kembali ke UUD 1945: sejak tanggal 5 Juli 1966 s/d sekarang.

Peraturan Pemerintah Pengganti Undang-Undang atau disingkat PERPPU, atau juga Perpu, adalah salah satu bentuk atau jenis peraturan perundang-undangan yang berlaku sebagaimana diatur dalam Pasal 22 ayat

(1), (2), dan (3) Undang-Undang Dasar 1945.

Keberadaan Pasal 22 tentang PERPPU ini secara historis tidak bisa dipisahkan dari pengaturan mengenai Undang-Undang Darurat dalam istilah Pasal 96 dan Pasal 97 UUD Sementara atau sama dengan Pasal 139 dan Pasal 140 Konstitusi RIS. ${ }^{4}$ Secara utuh sebagai perbandingan, di sini dicantumkan pasal yang terkait mengenai Undang-Undang Darurat, atau yang sekarang ini disebut PERPPU, berikut penjelasan dari Prof. DR.R.Soepomo, 5 yaitu:

Pasal 96

(1) Pemerintah berhak atas kuasa dan tanggungdjawab sendiri menetapkan undang-undang darurat untuk mengatur hal-hal penjelenggaraanpemerintahan jang karena keadaan-keadaan jang mendesak perlu diatur dengan segera.

(2) Undang-undang darurat mempunjai kekuasaan dan deradjat undang-undang; ketentuan ini tidak mengurangi jang ditetapkan dalam pasal jang

4 Ahmad Yani, S.H.,M.H.,Pembentukan Peraturan Perundang-undangan yang responsif, Konstitusi Press (KonPress), Jakarta, 2013.

5 Prof.Dr.R.Soepomo,Undang-Undang Dasar Sementara Republik Indonesia, Jakarta: Penerbit NoordhoffKolff N.V.,1954: 108-11. berikut.

Penjelasan:

Pasal ini adalah sama dengan Pasal 139 Konstitusi

RIS. Perkataan "kuasa undang-undang" di dalam

Konstitusi RIS diganti dengan perkataan yang lebih tepat, ialah "deradjat undang-undang".

Menurut Djawaban Pemerintah RIS atas Laporan Panitya Pelapor DPR tertanggal 3 Agustus 1950, maka adanja pasal ini bukanlah untuk memberi kesempatan bagi Pemerintah melampaui garisgaris demokrasi, melainkan untuk mengatasi berbagai-bagai kesulitan pada masa pemulaan ini. Dalam berbagai hal perlu diadakan peraturanperaturan jang tjepat untuk melaksanakan pemerintahan. Keadaan itu dapat begitu mendesak, sehingga peraturan itu tidak dapat ditangguhkan sampai adanja sidang Parlemen dan selesainja perundingan tentang hal itu dalam Parlemen.

Undang-undang darurat mempunjai kekuasaan undang-undang, djadi sebagai undang-undang, undang-undang darurat dapat mengantjam dengan hukuman, dengan tidak terbatas seperti halnja dengan Peraturan Pemerintah.

Undang-undang darurat adalah sederadjat dengan undang-undang, sehingga undangundang darurat dapat berubah atau menambah pasal-pasal undang-undang.

Menurut teks Pasal 96 ajat 1, maka pembentukan undang-undang darurat hanja diperbolehkan untuk mengatur hal-hal penjelenggaraan pemerintahan, djadi tidak boleh digunakan untuk mengatur hal jang bukan bersifat penjelenggaraan pemerin-tahan.

Akan tetapi hal penjelenggaraan pemerintahan adalah sangat luas, jaitu segala hal jang masuk dalam definisi, jang dimuat dalam Pasal 82, sehingga di dalam praktek tidak akan mudah menundjuk suatu hal di luar lingkungan Pasal 82 tersebut. Pasal 82 berbunji: Pemerintah menjelenggarakan kesedjahteraan Indonesia dan teristimewa berusaha supaja Undang-Undang Dasar, undang-undang dan peraturan-peraturan lain didjalankan. 
Pasal 97

(1) Peraturan-peraturan jang termaktub dalam undangundang darurat, sesudah ditetapkan, disampaikan kepada Dewan Perwakilan Rakjat selambat-lambatnja pada sidang jang berikut jang merundingkan peraturan ini menurut jang ditentukan tentang merundingkan usul undang-undang Pemerintah.

(2) Djika suatu peraturan jang dimaksud dalam ajat jang lalu, waktu dirundingkan sesuai dengan ketentuan-ketentuan bagian ini, ditolak oleh Dewan Perwakilan Rakjat, maka peraturan itu tidak berlaku lagi karena hukum.

(3) Djika undang-undang darurat jang menurut ajat jang lalu tidak berlaku lagi, tidak mengatur segala akibat jang timbul dari peraturannja-baik jang dapat dipulihkan maupun jang tidak- maka undang-undang mengadakan tindakan tindakan jang perlu tentang itu.

(4) Djika peraturan jang termaktub dalam undangundang darurat itu diubah dan ditetapkan sebagai undang-undang, maka akibat-akibat perubahannja diatur pula sesuai dengan jang ditetapkan dalam ajat jang lalu.

Penjelasan:

Isi pasal ini adalah sama dengan isi Pasal 140 Kon-stitusi RIS. Pasal ini adalah imbangan daripada Pasal 96. Atas Pasal 97 ini DPR dapat mengoreksi perbuatan Pemerintah.

Peraturan-peraturan jang termaktub dalam undang-undang darurat itu disampaikan kepada DPR dalam bentuk rantjangan undang-undang.

Undang-undang itu berbentuk undang-undang penetapan undang-undang darurat jang bersangkutan sebagai undang-undang (biasa), sedang isi (peraturanperaturan) undang-undang darurat diulangi lagi (dengan segala perubahan-perubahan jang ditetapkan bersama oleh DPR dan Pemerintah) dalam undangundang penetapan tersebut.

Walaupun secara historis PERPPU tidak bisa dipisahkan dari pengaturan Undang-Undang Darurat dalam istilah Pasal 96 dan Pasal 97 UUD Sementara atau sama dengan Pasal 139 dan Pasal 140 Konstitusi
RIS, tetapi menurut Prof.Dr.Jimly Asshidiqie,S.H., penamaan Peraturan Pemerintah Pengganti UndangUndang adalah sangat berbeda dengan ketentuan yang terdapat dalam Konstitusi RIS 1949 dan UUDS 1950. Kedua undang-undang dasar ini sama-sama menggunakan istilah undang-undang darurat untuk pengertian yang mirip atau serupa dengan PERPPU. ${ }^{6}$

\section{Pengertian PERPPU}

Istilah peraturan pemerintah sebagai pengganti undang-undang ini sepenuhnya adalah ciptaan Undang-Undang Dasar 1945 yang berbunyi, "Dalam hal ihwal kegentingan yang memaksa, Presiden berhak menetapkan peraturan pemerintah sebagai pengganti undang-undang”. Dalam Pasal 22 ayat (2)_nya dinyatakan, "Peraturan pemerintah itu harus mendapat persetujuan Dewan Perwakilan Rakyat dalam persidangan yang berikut”, dan ayat (3)_nya menentukan, "Jika tidak mendapat persetujuan, maka peraturan pemerintah itu harus dicabut".

Dari kutipan-kutipan di atas dapat diketahui bahwa:

- Peraturan tersebut disebut Peraturan Pemerintah sebagai Pengganti

- Undang-Undang, yang berarti bahwa bentuknya adalah Peraturan Pemerintah (PP) sebagaimana dimaksud dalam Pasal 5 ayat (2) UUD 1945. Pasal 5 ayat (2) ini menyatakan, "Presiden menetapkan peraturan pemerintah untuk menjalankan undangundang sebagaimana mestinya". Jika biasanya bentuk Peraturan Pemerintah itu adalah peraturan yang ditetapkan untuk menjalankan undang-undang sebagaimana mestinya, maka dalam keadaan kegentingan yang memaksa bentuk Peraturan Pemerintah itu dapat dipakai untuk menuangkan ketentuan-ketentuan yang semestinya dituangkan dalam bentuk undang-undang dan untuk menggantikan undang-undang.

Pada pokoknya, peraturan pemerintah sebagai pengganti undang-undang itu sendiri bukanlah nama resmi yang diberikan oleh UUD 1945. Namun, da-

6 Jimly Asshiddiqie, Perihal Undang-Undang, Rajawali Pers, Jakarta, 2011, Hlm.56. 
lam praktik selama ini, peraturan pemerintah yang demikian itu lazim dinamakan sebagai Peraturan Pemerintah (tanpa kata 'sebagai') Pengganti UndangUndang atau disingkat PERPU atau biasa juga ditulis PERPPU. Oleh karena itu, dalam praktek sehari-hari, kelaziman itu diterima saja apa adanya sehingga produk hukum peraturan pemerintah sebagai pengganti undang-undang itu dapat secara resmi disebut sebagai PERPPU atau Peraturan Pemerintah Pengganti Undang-Undang. Penamaan demikian ini sangat berbeda dari ketentuan yang terdapat dalam Konstitusi RIS 1949 dan UUDS 1950. Kedua undang-undang dasar ini sama-sama menggunakan istilah undangundang darurat untuk pengertian yang mirip atau serupa dengan PERPPU. ${ }^{7}$

PERPPU tersebut pada pokoknya hanya dapat ditetapkan oleh Presiden apabila persyaratan "kegentingan yang memaksa" itu terpenuhi sebagaimana mestinya. Keadaan "kegentingan yang memaksa" yang dimaksud di sini berbeda dan tidak boleh dicampur adukkan dengan pengertian "keadaan bahaya" sebagaimana ditentukan oleh Pasal 12 UUD 1945. Pasal 12 tersebut menyatakan, "Presiden menyatakan keadaan bahaya. Syarat-syarat dan akibatnya keadaan bahaya ditetapkan dengan undang-undang”. Kedua ketentuan Pasal 12 dan Pasal 22 ayat (1), (2), dan (3) UUD1945 tersebut sama-sama berasal dari ketentuan asli UUD 1945, yang tidak mengalami perubahan dalam Perubahan Pertama sampai dengan Perubahan Keempat. Artinya, norma dasar yang terkandung di dalamnya tetap tidak mengalami perubahan.

Oleh karena itu, sebagai dokumen historis, uraian penjelasan atas pasal-pasal ini dalam naskah Penjela-san (tentang) UUD 1945 dapat dijadikan rujukan untuk memahami rumusan kedua pasal ini, terutama Pasal 22 secara lebih mendalam. Dalam penjelasan Pasal 22 itu dinyatakan,

"Pasal ini mengenai noodverordeningsrecht

Presiden. Aturan ini memang perlu diadakan agar supaya keselamatan negara dapat dijamin oleh

7 Di sini sengaja disebut 'mirip' atau 'serupa', karena pada pokoknya antara PERPPU menurut UUD 1945 dan undang-undang darurat menurut Konstitusi RIS Tahun 1949 dan UUDS Tahun 1950 itu memang tidak terdapat perbedaan yang prinsipil. pemerintah dalam keadaan yang genting, yang memaksa pemerintah untuk bertindak lekas dan tepat. Meskipun demikian, pemerintah tidak akan terlepas dari pengawasan Dewan Perwakilan Rakyat. Oleh karena itu, peraturan pemerintah dalam pasal ini, yang kekuatannya sama dengan undang-undang harus disahkan pula oleh Dewan Perwakilan Rakyat".

"Keadaan bahaya" seperti yang dimaksud oleh Pasal 12 UUD 1945 memang dapat menjadi salah satu sebab terpenuhinya persyaratan "kegentingan yang memaksa" menurut ketentuan Pasal 22 ayat (1) UUD 1945 itu. Akan tetapi, "kegentingan yang memaksa" menurut ketentuan Pasal 22 itu tidak selalu bersumber dari "keadaan bahaya" menurut ketentuan Pasal 12. Pengertian bahaya itu dapat saja diartikan sebagai ancaman yang datang dari luar atau ancaman eksternal, tetapi keadaan "genting dan memaksa" dapat timbul sebagai ancaman dari luar ataupun sebagai akibat tuntutan yang tidak terelakkan dari dalam.

Dari segi lain, "keadaan bahaya" yang datang dari luar itu dapat dilihat secara objektif fakta-fakta objektifnya, sehingga objektif atau atau tidaknya dinilai oleh Dewan Perwakilan Rakyat. Sedangkan "kegentingan yang memaksa" timbul dari penilaian subjektif Presiden belaka mengenai tuntutan mendesak dari dalam pemerintahannya untuk bertindak cepat dan tepat mengatasi keadaan yang genting.

Oleh karena itu, sangatlah penting mengembangkan pengertian bahwa PERPPU itu sebenarnya secara materiil adalah undang-undang juga, hanya bentuknya bukan undang-undang. Bajunya Peraturan Pemerintah, tetapi isinya adalah undangundang, yaitu undang-undang dalam arti materiil atau "wet in matriele zin". Dengan demikian, PERPPU itu sebagai undang-undang dalam arti materiil itu dapat saja diuji konstitusionalitasnya oleh Mahkamah Konstitusi sebagaimana mestinya.

Karena materi PERPPU itu seharusnya dituangkan dalam bentuk undang-undang, maka masa berlakunya PERPPU itu dibatasi hanya untuk sementara. Menu-rut ketentuan Pasal 22 ayat (2) dan (3) UUD 1945, 
"Peratutan pemerintah itu harus mendapat persetujuan Dewan Perwakilan Rakyat dalam persidangan beri-kut". "Jika tidak mendapat persetujuan, maka pera-turan pemerintah itu harus dicabut". Karena itu, masa berlakunya PERPPU itu paling lama adalah 1 tahun. Jika dalam waktu 1 tahun masa persidangan DPR, PERPPU itu tidak mendapat persetujuan sebagaiman mestinya, berarti PERPPU itu harus dicabut. Mengenai jangka waktu berlakunya "emergency legislation" ini, di berbagai negara diatur secara berbeda-beda satu sama lain.

Dalam Pasal 52 UU No.12 Tahun 2011 tentang Pembentukan Peraturan Perundang-undangan, hal tersebut diatur secara berbeda sama sekali. Pasal 25 undang-undang ini menentukan:

1. Peraturan Pemerintah Pengganti UndangUndang harus diajukan ke Dewan Perwakilan Rakyat da-lam persidangan yang berikut;

2. Pengajuan Peraturan Pemerintah Pengganti Undang-Undang sebagaimana dimaksud pada ayat (1) dilakukan dalam bentuk pengajuan rancangan undang-undang penetapan peraturan pemerintah pengganti undang-undang menjadi undang-undang;

3. Dalam hal Peraturan Pemerintah Pengganti Undang-Undang ditolak Dewan Perwakilan Rakyat, maka Peraturan Pemerintah Pengganti Undang-Undang tersebut tidak berlaku;

4. Dalam hal Peraturan Pemerintah Pengganti Undang-Undang ditolak Dewan Perwakilan Rakyat, maka Presiden mengajukan rancangan undang-undang tentang pencabutan Peraturan Pemerintah Pengganti Undang-Undang tersebut yang dapat mengatur pula segala akibat dari penolakan tersebut.

Namun demikian, terlepas dari ketentuan Pasal 52 UU No.12 Tahun 2011, dari uraian-uraian tersebut di atas, dapat diketahui bahwa:

PERPPU atau Peraturan Pemerintah Pengganti Undang-Undang sebagai bentuk "emergency legislation", yang lahir dari adanya noodverordeningsrecht Presiden Republik Indonesia berdasarkan UUD 1945 adalah produk peraturan yang mempunyai kedudukan yang sama kuat dan bahkan sederajat dengan undang-undang;

Dari segi bentuknya, PERPPU itu adalah Peraturan Pemerintah (PP), tetapi dari segi isinya PERPPU itu identik dengan undang-undang. Karena itu, PER-PPU itu dapat disebut sebagai undangundang dalam arti materiil atau "wet materiele zin";

Sebagai produk undang-undang dalam arti materiil, penerbitan dan pelaksanaan PERPPU itu harus diawasi dengan ketat oleh DPR-RI. Bahkan dapat dikatakan pengawasan oleh DPR haruslah diprioritaskan. Namun, keharusan prioritas pengawasan oleh DPR itu tidak menutup kemungkinan, apabila syarat-syarat untuk itu terpenuhi, misalnya, penerapan PERPPU tersebut sungguh-sungguh telah menimbulkan korban ketidak adilan yang sangat serius, maka PERPPU itu dapat pula dijadikan objek pengujian oleh Mahkamah Konstitusi.

Penentuan adanya syarat timbulnya korban ketidak adilan yang serius itu dimaksudkan untuk memelihara prinsip bahwa sebenarnya, PERPPU itu belumlah menjadi objek pengujian norma hukum (norm control mechanism) oleh Mahkamah Konstitusi. PERPPU sebagai bentuk "emergency legialation" dengan penyimpangan norma yang terkandung di dalamnya, sudah seharusnya lebih dulu menjadi objek pengawasan ketat yang diprioritaskan oleh DPR-RI. Jika dalam masa pengawasan oleh DPR tersebut, penerapan PERPPU tersebut sudah menimbulkan korban ketidakadilan yang nyata, maka tidak selayaknya bagi Mahkamah Konstitusi sebagai pengawal undang-undang dasar untuk membiarkan ketidakadilan itu menimbulkan masalah yang lebih besar, terutama apabila PERPPU tersebut telah diajukan oleh pihak yang dirugikan hak konstitusionalnya sebagai perkara di Mahkamah Konstitusi. Jika korban yang hak atau kewenangan konstitusionalnya nyata-nyata memang dirugikan oleh berlakunya PERPPU itu mengajukan permohonan perkara pengujian kepada Mahkamah Konstitusi, maka tidak ada alasan bagi lembaga pengawal konstitusi ini kecuali memeriksa, mengadili, dan memutus perkara 
pengujian konstitusionalitas Peraturan Pemerintah Pengganti Undang-Undang itu sebagai undang-undang dalam arti materiil (wet materiil zin) dengan cara yang sebaik-baiknya menurut UUD 1945 dan UU No.24 Tahun 2003 tentang Mahkamah Konstitusi.

\section{Batasan Konstitusional PERPPU}

Di dalam UUD 1945 telah secara tegas diatur peri-hal negara dalam keadaan genting atau darurat. Pasal 22 berbunyi, "Dalam hal ihwal kegentingan yang memaksa Presiden berhak mengeluarkan peraturan pemerintah pengganti undang-undang. Peraturan pemerintah itu harus mendapat persertujuan DPR dalam persidangan yang berikut. Jika tidak menda-pat persetujuan, maka peraturan pemerintah harus dicabut."

Ketentuan dalam Pasal 22 tersebut mengisyaratkan apabila keadaannya lebih genting dan amat terpaksa dan memaksa, tanpa menunggu adanya syarat-syarat yang ditentukan lebih dahulu oleh dan dalam suatu undang-undang, serta bagaimana akibat-akibat yang tidak sempat ditunggu dan ditetapkan dalam suatu undang-undang, Presiden berhak menetapkan PERPPU sekaligus menyatakan suatu keadaan bahaya dan darurat. $^{8}$

Siapakah yang menetukan dan dalam keadaan seperti apakah kondisi yang disebut sebagai 'hal ikhwal kegentingan yang memaksa' telah terpenuhi sehingga Presiden menjadi berhak menetapkan PERPPU? Menurut Jimly Asshidiqie, rumusan tersebut sebenarnya dapat kita sebut termasuk kategori "objective wording" seperti yang dimaksud oleh Cora Hoexter. Artinya, hak Presiden dimaksud tidak meniadakan hak DPR untuk mengontrol penetapan PERPPU itu. Jika kelak DPR menyatakan persetujuannya, barulah PERPPU itu diakui berlaku sebagai undangundang. Jika peraturan itu ditolak oleh DPR, peraturan itu selanjutnya harus dicabut sebagaiman mestinya. Dengan perkataan lain, penentuan keadaan darurat itu sendiri tidak semata-mata

8 Ni'matul Huda, Politik Ketatanegaraan Indonesia, Cetakan Pertama,FH UII Press, Yogyakarta,2003,Hlm.140. tergantung kepada kehendak subjektif Presiden, melainkan tergantung pula kepada kehendak para wakil rakyat di DPR. Oleh karena itu, perumusan seperti demikian dinamakan oleh Hoexter sebagai "objective wording".

Namun dari sudut pandang kekuasaan Presiden, hak untuk menetapkan PERPPU atas dasar penilaian Presiden sendiri yang bersifat sepihak mengenai adanya hal ikhwal kegentingan yang memaksa itu, dapat dikatakan bahwa hal itu bersifat subjektif. Artinya, ketika PERPPU ditetapkan oleh Presiden berdasarkan ketentuan Pasal 22 ayat (1) UUD 1945, penentuan adanya hal ikhwal yang memaksa sebagai prasyarat dapat dikatakan semata-mata didasarkan atas penilaian subjektif, yaitu berdasarkan subjektivitas kekuasaan Presiden sendiri. Penilaian mengenai 'hal ikhwal kegentingan yang memaksa' itu baru menjadi objektif setelah hal itu dinilai dan dibenarkan adanya oleh DPR berdasarkan ketentuan Pasal 22 ayat (2) UUD 1945.

\section{Kelayakan Sosiologis Menerbitkan PERPPU}

Jika kita kaji dalam kasus MK, rasanya berlebihan kalau tertangkapnya Ketua MK (saat itu) Akil Mokhtar telah menimbulkan kegentingan dan mendesak dikeluarkannya PERPPU. Akil Mokhtar terlalu 'mahal' kalau harus 'dibeli' oleh Pemerintah dengan PERPPU. Perilaku satu orang belum tentu mencerminkan seluruh hakim konstitusi (institusi). Kalau pun PERPPU MK dimaksudkan untuk menyelamatkan kelembagaan MK, kondisi hakim konstitusi jumlahnya masih ada 8 (delapan) orang yang bisa bekerja secara maksimal. Di samping itu, kuorum Rapat Permusyawaratan Hakim (RPH) untuk mengambil keputusan, mensyaratkan sekurang-kurangnya 7 (tujuh) orang Hakim Konsti-tusi dan Putusan dalam RPH juga dihadiri sekurangkurangnya 7 (tujuh) orang Hakim Konstitusi. ${ }^{9}$

Artinya, belumlah cukup beralasan dan berlebihan

9 Lihat dalam PMK No.06/PMK/2005 jo PMK No.08/PMK/2006 jo PMK No.12/PMK/2008 jo PMK No.15/PMK/2008 jo PMK No.16/PMK/2009 jo PMK No.17/PMK/2009 jo PMK No.21/ PMK/2009. Semua PMK ini di dalamnya antara lain mengatur tentang kuorum Rapat Permusyawaratan Hakim (RPH) untuk mengambil keputusan, serta syarat untuk pengambilan putusan dalam RPH Hakim Konstitusi. 
jika untuk mensikapi kasus Akil Mokhtar harus dikeluarkan PERPPU.

Alih-alih Presiden akan melakukan penyelamatan dan mengembalikan kepercayaan publik terhadap MK melalui PERPPU No.1 Tahun 2013, ternyata penyusunan PERPPU tersebut kurang cermat dan berakibat fatal bagi kelembagaan MK sendiri. Jika dibaca Konsiderans "Menimbang" huruf $b,{ }^{10}$ yang berbunyi:"bahwa untuk menyelamatkan demokrasi dan negara hukum Indonesia, serta untuk mengembalikan kepercayaan publik tehadap MK sebagai lembaga negara yang menjalankan fungsi menegakkan UUD, akibat adanya kemerosotan integritas dan kepribadian yang tercela dari hakim konstitusi, perlu dilakukan perubahan kedua atas UU No.24 Tahun 2003 tentang Mahkamah Konstitusi”. Melalui rumusan dalam Konsideran (cetak miring) tersebut, Presiden telah memberikan stigma bahwa 'seluruh' hakim konstitusi memiliki kepribadian yang tercela, sehingga layak untuk dijadikan sandaran argumentasi "adanya kegentingan yang memaksa", padahal yang terkena kasus hanya Akil Mochtar.

Dalam ilmu perundang-undangan, Konsiderans memiliki nilai strategis dalam suatu perundang-undangan, karena didalamnya memuat pokok-pokok pikiran yang menjadi latar belakang dan alasan pembuatan

10 PERPPU MK yang dijadikan acuan dalam penulisan ini adalah PERPPU versi Wamen Hukum dan HAM Denny Indrayana yang beredar luas. Isi Konsiderans 'Mengingat' huruf b sebagaiman dikritisi di atas sudah dilakukan ralat. Menurut penuturan Menteri Hukum dan HAM Amir Syamsudin, hilangnya konsiderans huruf $b$ tersebutbukan karena revisi, tetapi naskah PERPPU yang resmi memang tidak mencantumkan hal itu. Naskah yang dikirimkan lewat e-mail oleh WamenkumHAM Denny Indrayana kemungki-nan masih berbentuk drfat. Lihat pemberitaan bertajuk "PERPPU MK,Dua Naskah Beredar,3 Advokat Uji Materi",Kompas,22 Ok-tober 2013, Hlm.1. Andai PERPPU MK yang beredar lebih dulu versi Wamenkumham itu masih draf, ada hikmahnya juga kare-na para hakim konstitusi ketika itu masih sempat memberikan pencermatan dan sikap tegasmenolak isu konsiderans tersebut., karena menyangkut marwah hakim-hakim konstitusi yang masih aktif. Konsideran 'Mengingat'huruf $b$ berubah berbunyi sebagai berikut:"bahwa untuk menyelamatkan demokrasi dan negara hu-kum Indonesia, serta untuk mengembalikan kepercayaan publik terhadap MK sebagai lembaga negara yang menjalankan fung-si menegakkan UUD, perlu dilakukan perubahan terhadap UU No.24 Tahun 2003 tentang Mahkamah Konstitusi sebagaimana telah diubah dengan UU No.8 Tahun 2011 tenatng Perubahan Atas UU No.24 Tahun 2003 tentang Mahkamah Konstitusi, te-rutama terhadap ketentuan mengenai syarat dan tata cara seleksi, pemilihan, dan pengajuan calon hakim konstitusi serta pemben-tukan majelis kehormatan hakim konstitusi". perundang-undangan, yakni unsur filosofis, juridis, politis, dan sosiologis, serta unsur administratif. ${ }^{11}$

Kalau demikian halnya posisi strategis dari Konsiderans dalam suatu peraturan perundangundangan, maka kesalahan meletakkan argumentasi filosofis, ju-ridis, politis, dan sosiologis di dalamnya bisa berakibat fatal bagi 'nasib' peraturan tersebut.

Dengan kata lain, jika PERPPU No.1 Tahun 2013 tentang MK diajukan pengujian ke MK, bisa dipastikan permohonan pengujian PERPPU tersebut akan dikabulkan, karena adanya kesalahan fatal di dalam 'jantungnya' sebuah peraturan perundang-undangan (PERPPU), khususnya Konsiderans huruf $b$.

\section{Pengujian PERPPU}

\section{Dapatkah MK menguji PERPPU?}

Secara konstitusional PERPPU menjadi ranahnya DPR untuk mengujinya secara political review/ legislative review (Pasal 22 ayat (2) dan (3) UUD 1945), tetapi praktik ketatanegaraan menunjukkan MK pernah menguji PERPPU tentang KPK (Putusan MK No. 138/ PUU-VII/2009) dan PERPPU tentang Bank Century (No. 145/PUU-VII/2009). Ada perluasan kewenangan di MK. Dalam Putusan MK No. 138/PUU-VII/2009, Mahkamah mendalilkan tentang kewenangannya untuk menguji PERPPU tersebut karena PERPPU melahirkan norma hukum dan sebagai norma hukum baru akan dapat menimbulkan:

- status hukum baru,

- hubungan hukum baru, dan

- akibat hukum baru.

Norma hukum tersebut lahir sejak PERPPU disahkan dan nasib dari norma hukum tersebut tergantung kepada persetujuan DPR untuk menerima atau menolak norma hukum PERPPU, namun demikian sebelum adanya pendapat DPR untuk menolak atau

\footnotetext{
11 Jimly Asshiddiqie, Perihal Undang-Undang, Konpress, Jakarta, 2006, Hlm.169-170.

Lihat juga Maria Farida Indrati Suprapto, Ilmu Perundangundangan(2), (Proses dan Teknik Pembentukannya), Kanisius, Yogyakarta, 2007, Hlm. 108. Lihat juga dalam UU No.12 Ta-hun 2011 tentang Pembentukan Peraturan Perundang-undangan, Konsiderans memuat uraian singkat mengenai pokok pikiran yang menjadi pertimbangan dan alasan pembentukan peraturan perundang-undangan.
} 
menyetujui PERPPU, norma hukum tersebut adalah sah dan berlaku seperti Undang-Undang. Oleh karena dapat menimbulkan norma hukum yang kekuatan mengikatnya sama dengan UndangUndang, maka terhadap norma yang terdapat dalam PERPPU terse-but Mahkamah dapat menguji apakah bertentangan secara materiil dengan UUD 1945. Dengan demikian Mahkamah berwenang untuk menguji PERPPU ter-hadap UUD 1945 sebelum adanya penolakan atau persetujuan oleh DPR, dan setelah adanya persetu-juan DPR karena PERPPU tersebut telah menjadi Undang-Undang.

Sejumlah Advokat yang sering bersidang di MK sudah mendaftarkan perkara pengujian PERPPU No. 1 Tahun 2013 ke MK yang diregistrasi perkara No. 9094/2013. Kalau DPR 'belum jelas' menjadwalkan persidangan untuk membahas PERPPU MK, ${ }^{12}$ kemudian MK segera melakukan pengujian PERPPU tersebut, tentu akan memunculkan persoalan baru di bidang ketatanegaraan Indonesia. Jika putusan MK sudah keluar sebelum persidangan DPR, dan putusannya menyatakan PERPPU MK bertentangan dengan UUD 1945, maka nasib PERPPU akan berakhir saat itu, karena sifat putusan MK final dan mengikat. Pertanyaan yang muncul, apakah DPR masih perlu bersidang membahas PERPPU MK? Dapatkah putusan MK mengintervensi mandat konstitusional DPR?

Secara konstitusional DPR tetap harus bersidang membahas PERPPU karena adanya amanat dari Pasal 22 UUD 1945. Kalau ternyata putusan DPR menolak PERPPU berarti keberlakuan PERPPU juga selesai (harus dicabut). Akan tetapi jika putusan MK menyatakan PERPPU tidak bertentangan dengan UUD 1945, tetapi putusan sidang (politik) di DPR menyatakan menolak PERPPU MK, maka putusan manakah yang sah di mata hukum? Tentu kembali lagi kepada lan-dasan konstitusional perihal PERPPU yang secara tegas dinyatakan menjadi kekuasaan DPR untuk

12 Badan Musyawarah DPR memberikan batas waktu kepada Komisi III DPR untuk menyelesaikan pembahasan PERPPU No.1 Tahun 2013 sebelum 20 Desember 2013. Kompas, 22 November 2013, Hlm.5. membahasnya dalam persidangan DPR. Sehingga putusan yang sah adalah yang diputus oleh DPR. Untuk itu, jika DPR sudah menjadwalkan sidang yang akan membahas PERPPU sebaiknya MK tidak menyidangkan pengujian PERPPU, untuk menghormari otoritas yang dimiliki DPR.

Rapat Paripurna DPR, Kamis 19 Desember 2013, menyetujui untuk menerima PERPPU No.1 Tahun 2013 tentang MK menjadi UndangUndang. Persetujuan tersebut dilakukan melalui pemungutan suara. Sebanyak 221 anggota DPR dari Fraksi Demokrat, Golkar, PAN, PPP, dan PKB menyatakan menyetujui menerima PERPPU MK. Sementara penolakan dilakukan oleh 148 anggota DPR dari Fraksi PDI-P, PKS, Gerindra, Hanura, dan PPP.13 Dengan adanya persetujuan DPR tersebut, maka permohonan untuk pengujian PERPPU MK di MK dihentikan. Pemohon dapat memperbaharui permohonannya kembali tetapi tidak untuk pengujian PERPPU MK tetapi pengujian UU MK yang baru, yakni UU No. 4 Tahun 2014 tentang Penetapan Peraturan Pemerintah Pengganti Undang-Undang Nomor 1 Tahun 2013 tentang Mahkamah Konstitusi.

Pada 13 Februari 2014, Mahkamah Konstitusi secara bulat membatalkan UU No.4 Tahun 2014 tentang Penetapan Peraturan Pemerintah Peng-ganti Undang-Undang Nomor 1 Tahun 2013 ten-tang Mahkamah Konstitusi secara keseluruhan.14 Pertimbangan MK membatalkan UU No.4 Tahun 2014 antara lain:

- Pertama, UUD 1945 Pasal 24C ayat (3) memberikan kewenangan atributif yang bersifat mutlak kepada Pemerintah, DPR, dan MA untuk mengajukan calon hakim konstitusi. Kewenangana tersebut tidak boleh diberikan syarat-syarat tertentu oleh UU dengan melibatkan lembaga negara lain yang tidak diberi kewenangan oleh UUD dalam hal ini KY. Oleh karena itu, UU No.4 Tahun 2014

13 Suara PPP terpecah, ada 20 orang anggota yang menyetujui PERPPU MK dan 3 orang anggotanya menyatakan menolak PERPPU MK. Baca,Kompas.

14 "Pemerintah Terkejut MK Secara Bulat Batalkan UU No.4/2014 tentang Penetapan PERPPU MK",Kompas, Jumat, 14 Pebruari 2014. 
yangmengatur pengajuan calon hakim konstitusi melalui panel ahli, perangkat yang dibentuk KY, nyata-nyata mereduksi kewenangan tiga lembaga tersebut.

- Kedua, terkait dengan Majelis Kehormatan Mahkamah Konstitusi yang diatur dalam UU No. 4 Tahun 2014, MK mempersoalkan keterlibatan KY meski tidak secara langsung. Sesuai dengan putusan MK No. 005/PUU-IV/2006 tentang pengujian UU KY, MK secara tegas menyatakan bahwa hakim KY tidak terkait dengan ketentuan yang diatur di dalam Pasal 24B UUD 1945. KY bukan lembaga pengawas MK, apalagi lembaga yang berwenang menilai benar atau tidaknya putusan MK sebagai lembaga peradilan. Pelibatan KY merupakan salah satu bentuk penyelundupan hukum, karena hal itu jelas bertentangan dengan putusan MK tentang UU KY.

- Ketiga, mengenai syarat calon hakim konsti-tusi tidak menjadi anggota partai politik selama tujuh tahun, syarat tersebut dibuat berdasarkan stigmatisasi terhadap kelompok tertentu pasca penangkapan Akil Mochtar yang saat itu menjadi Ketua MK. Stigmatisasi seperti itu mencederai hak konstitusional warga negara yang dijamin konstitusi. Bahwa korupsi haruslah diberantas adalah benar, tetapi memberikan stigma dengan menyamakan semua anggota partai politik sebagai calon koruptor dan oleh karena itu berkepribadian tercela serta tidak dapat berlaku adil sehingga tidak memenuhi syarat menjadi hakim konstitusi adalah suatu penalaran yang tidak benar. Perilaku tercela dan tidak adil merupakan tabiat individual yang harus dilihat secara individual juga.

- Keempat, MK menilai penerbitan PERPPU No.1 Tahun 2013 tidak sesuai dengan ketentuan karena tidak memenuhi syarat kegentingan yang memaksa yang diatur UU. Menurut MK, PERPPU harus mempunyai akibat prompt immediately, yaitu sontak segera untuk memecahkan permasalahan hukum. PERPPU No. 1 Tahun 2013 tidak memenuhi hal tersebut, terbukti dengan belum adanya satu produk hukum yang dihasilkan PERPPU. Panel ahli sampai dengan saat PERPPU tersebut ditetapkan menjadi Undang-Undang dan bahkan sampai dengan Undang-Undang Penetapannya dibatalkan oleh MK, belum kunjung terbentuk. Perekrutan hakim konstitusi untuk mengganti M. Akil Mochtar belum dapat dilakukan, justru semakin tertunda karena adanya ketentuan yang terdapat dalam PERPPU.

\section{Kesimpulandan Saran}

Kesimpulan dan saran yang didapat penulis dari kajian tentang Perppu Nomor 1 Tahun 2013 tentang Perubahan Kedua Atas Undang-Undang Nomor 24 Tahun 2003 tentang Mahkamah Konstitusi adalah bahwa penerbitan Perppu Nomor 1 Tahun 2013 Tentang Perubahan Kedua atas Undang-Undang Nomor 24 Tahun 2003 Tentang Mahkamah Konstitusi tidak sesuai dengan ketentuan perundang-undangan yang berlaku. Perihal keadaan 'genting yang memaksa' sebagaimana dipersyaratkan oleh Pasal 22 UUD 1945 belum tercukupi untuk melahirkan Perppu MK, karena tidak muncul krisis yang berkepanjangan dan mendesak. Presiden dan menteri yang terkait serta jajarannya hendaknya lebih cermat dan berhati-hati dalam menggunakan pertimbangan 'subjektifnya' saat memutuskan untuk menyusun dan menerbitkan suatu Perppu. Karena apabila ternyata kemudian Perppu tersebut ditolak oleh DPR atau oleh MK, atau bahkan bila ditolak secara bulat oleh dua lembaga tersebut, maka kredibilitas Presiden sebagai Pemimpin Negara akan tereduksi. Paling tidak dalam hal Ketatanegaraan. Tentu hal itu harus 'dihindari' dalam praktik bernegara.

\section{Daftar Pustaka}

Buku

Ahmad Yani, Pembentukan Peraturan Perundangundangan yang responsif, Konstitusi Press

(Kon-Press), Jakarta, 2013.

Aziz Syamsuddin, Proses dan Teknik Penyusunan Undang-undang, Sinar Grafika, Jakarta, 2013. 
I Gde Pantja Astawa dan Suprin Na'a, S.H.,M.H. Dinamika Hukum dan Ilmu Perundang-undangan di Indonesia, PT. Alumni, Bandung, 2012.

Jimly Asshiddiqie, Pengantar Ilmu Hukum Tata

Neg-ara, PT. Rajagrafindo Persada, Jakarta, 2011.

Jimly Asshiddiqie, Perihal Undang-Undang, Rajawali Pers, Jakarta, 2011.

L. J. van Apeldoorn, Pengantar Ilmu Hukum, PT. Pradnya Paramita, Jakarta, 1993.

Maria Farida Indrati S, Ilmu Perundang-undangan (I) Jenis Fungsi dan Materi Muatan, Kanisius, Yogyakarta, 2007.

Maria Farida Indrati S, Ilmu Perundang-undangan (2) Proses dan Teknik Pembentukannya, Kanisius, Yogyakarta, 2007.

Ni'matul Huda, Perkembangan Hukum Tata Negara, Perdebatan dan Gagasan Penyempurnaan, Cetakan Pertama, UII Press, Yogyakarta,2014.

Undang-Undang, Peraturan, Rancangan, Dan Putusan

UNDANG-UNDANG DASAR 1945, Pasal 22.

PERPU NOMOR 1 TAHUN 2013 TENTANG PERUBAHAN KEDUA ATAS UNDANG-UNDANG NOMOR 24 TAHUN 2003 TENTANG MAHKAMAH KONSTITUSI, Yogyakarta, 17 Oktober 2013.

UNDANG-UNDANG NOMOR 4 TAHUN 2014 TENTANG PENETAPAN PERPU NOMOR 1 TAHUN 2013 TENTANG PERUBAHAN KEDUA ATAS UNDANG-UNDANG NOMOR 24 TAHUN 2003 TENTANG MAHKAMAH KONSTITUSI MENJADI UNDANG-UNDANG, Jakarta, 17 Oktober 2013.
PUTUSAN MAHKAMAH KONSTITUSI REPUBLIK INDONESIA NOMOR 1-2/PUU-XII/2014 PERIHAL PENGUJIAN UNDANG-UNDANG NOMOR 4 TAHUN 2014 TENTANG PENETAPAN PERATURAN PEMERINTAH PENGGAN-TI UNDANG-UNDANG NOMOR 1 TAHUN 2013 TENTANG PERUBAHAN KEDUA ATAS UNDANG-UNDANG NOMOR 24 TAHUN 2003 TENTANG MAHKAMAH KONSTITUSI MENJADI UNDANGUNDANG, Jakarta, 13 Februari 2014.

UNDANG-UNDANG NOMOR 12 TAHUN 2011 TENTANG PEMBENTUKAN PERATURAN PERUNDANG-UNDANGAN， Jakarta， 12 Agus-tus 2011 .

UNDANG-UNDANG NOMOR 10 TAHUN 2004 TENTANG PEMBENTUKAN PERATURAN PERUNDANG-UNDANGAN, Jakarta, 22 Juni 2004.

PERPRES NOMOR 68 TAHUN 2005 TENTANG TATA CARA MEMPERSIAPKAN RANCANGAN UNDANG-UNDANG， RANCANGAN PERATURAN PEMERINTAH PENGGANTI UNDANG-UNDANG, RANCANGAN PERATURAN PEMERINTAH, DAN RANCANGAN PERATURAN PRESIDEN, Jakarta, 14 November 2005. 